\title{
Social Responsibility in Investment Policy and the Prudent Man Rule
}

\author{
Ronald B. Ravikoff $†$ \\ Myron P. Curzan $\ddagger$
}

The "prudent man" rule acts as a constraint on the discretionary investment decisionmaking of trustees and investment managers. The rule has conventionally been imterpreted as requiring a fiduciary to promote two traditional imvestment objectives: attainment of an adequate return and preservation of the trust corpus. ${ }^{1}$ As a general proposition, these have been the only objectives that trustees have sought in practice. Recently, however, this conception of the fiduciary's duties has come under attack. Numerous commentators have urged that trustees should be able to pursue other, nontraditional objectives in their investment practices. ${ }^{2}$ These commentators believe that the resources of various institutional funds sliould be employed to furtler worthy social goals. $^{3}$

$\dagger$ B.S. 1970, M.R.P. 1972, Cornell University; J.D. 1977, University of Miami Law School. Member, District of Columbia Bar.

\$ B.A. 1961, Columbia University; M.A. 1962, Yale University; L.L.B. 1965, Columbia Law School. Member, District of Columbia Bar.

1. Carlton's Estate v. Commissioner, 298 F.2d 415, 418 (2d Cir. 1962) ("[A] trustee is obliged not only to attempt to employ profitably the corpus but must also take care to preserve it."); Restatement (SECOND) OF Trusts \& 227, Comment a, at 529-30 (1959) [hereinafter cited as RESTATEMENT] ("[T] he trustee is under a duty to the beneficiary to use reasonable care and skill to preserve the trust property . . . and to make it productive . . . ."); III A. SCOTT, THE LAW OF TRUSTS $\$ 227$ (3d ed. 1967) ("It is the duty of a trustee to preserve the trust property and to make it productive.").

2. See, e.g., J. Rifkin \& R. Barber, The North Will Rise Again (1978); J. Simon, C. Powers, \& J. Gunneman, The Ethical Investor (1972); M. Weiss \& B. Behn, Pension Funds and Control of Capitalism (1978) (unpublished manuscript); Do Institutional Investors Have a Social Responsibility?, Institutional INVESTOR, March 1977, at 124; Baldwin, The Prudent Investor Rule and the Non-Discriminatory Investment Clause in Wisconsin (August 1977) (unpublished report to the Board of Regents of the University of Wisconsin System); B. LongSTRETH \& H. ROSENBLOOM, CORPORATE SOCIAL RESPONSIBILITY AND THE INSTITUTIONAL INVESTOR (1973).

3. Some of the most commonly articulated, "nontraditional" investment goals are to discourage involvement with South Africa, foster pro-union sentiment, foster sound environmental practices, enhance the local economy, and create new jobs. See, e.g., Wall St. J., Mar. 21, 1978, at 1 , col. 5 (International Longshoremen's \& Warehousemen's Union will not invest pension funds in companies doing business in South Africa); YALE WEEkLY Bull. 1, (Supp. April 24-May 8, 1978) (University adopts policy on investments relating to South Africa) (on file with California Law Review); E. Coltman \& S. Metzenbaum, Investing in Ourselves, C-7 (1979) (United Mine Workers 
This Article examines whether a trustee who invests trust funds to foster political, social, or other nontraditional objectives coinplies with the prudent man rule. The legitimacy of pursumg nontraditional imvestment goals becomes an issue only when a fiduciary sacrifices the traditional objectives-adequate return and corpus safety-in doing so. Where a fiduciary makes an investment on the basis of social or moral considerations but the investment nevertheless yields an adequate return and protects the trust corpus, the fiduciary's nontraditional motivations do not conflict with the conventional view of the prudent man rule. Where, on the other hand, the socially motivated investment provides a less-than-adequate rate of return or places the corpus in significant risk, the prudence of such an investment is likely to be challenged.

There is a notable absence of clear legal precedent on this issue. Presently, it is uncertain whether and to what extent a trustee inay pursue, consistently with the prudent man standard, nontraditional investment objectives at the expense of adequate return and corpus safety. This Article suggests, however, that existing case law, though quite sparse, can be read to permit such a practice. Moreover, statutory formulations of the prudent man rule can also be interpreted to permit trustees some freedom to pursue nontraditional objectives. The real debate, it seems, will be over the limitations that courts will impose on investment practices that foster nontraditional goals.

Part I of the Article demonstrates that the prudent man rule is not a unitary concept; indeed, there are various interpretations of the rule that would allow trustees to promote nontraditional investment objectives at the expense of adequate return and corpus safety. This is illustrated by examining the prudent man rule at common law, as articulated by commentators, and as used in the Employee Retirement Income Security Act ${ }^{4}$ (ERISA) and the Uniform Management of Institutional Funds Act ${ }^{5}$ (Uniform Act).

Part II constructs an analytic frainework for the prudent man standard. It argues that there are five primcipal interpretations of the standard. Depicted as poimts on a continuum, the interpretations are arranged according to the degree of freedoin each gives a trustee to promote nontraditional investment objectives. The section then de1nonstrates where common law, ERISA, and Uniform Act trustees may be able to operate on the contmuum-using the interpretations of the

will divest stock in antiunion companies) (on file with California Law Review); id. (International Ladies Garment Workers Union will consider investment targets' labor relations policies); id. at C-8 (University of Wisconsin will divest stock in companies that practice discrimination).

4. 29 U.S.C. $\S 1001$ et seq. (Supp. IV 1974) [hereinafter ERISA citations will be to the Act's section numbers as adopted rather than to the United States Code].

5. UNIFORM MGT. OF INSTIT. FUNDS ACT. 
prudent inan standard explored in Part I. Finally, the section identifies several factors that trustees should evaluate in determining the extent to which they may prudently sacrifice adequate return and corpus safety to promote nontraditional investment goals.

\section{I}

\section{The Prudent Man Rule}

This section explores the prudent man rule at common law, as viewed by various commentators, and as set forth in ERISA and the Uniform Act.

\section{A. The Common Law}

The Restatement (Second) of Trusts defines a trustee's investment obligations at common law as follows:

[i]n making investments of trust funds the trustee is under a duty to the beneficiary. . . to make such investments and only such imvestments as a prudent man would make of his own property having in view the preservation of the estate and the amount and regularity of the income to be derived....6

Courts have placed various limitations on the trustee's discretionary authority to buy and sell trust assets. Thus, the trustee's power can be exercised only for "proper motives." A court will "control the. trustee in the exercise of a power when he acts from an improper even though not a dishonest motive, that is, where he acts from a motive other than to further the purposes of the trust."8

The question is, what motives do courts consider "proper" and therefore permissible for a trustee to pursue in his or her imvestments? Clearly, the two objectives described in the statement of the common law's prudent man rule-preservation of the trust corpus and attainment of an adequate return-are permissible. Indeed, courts have traditionally evaluated the prudence of an investment exclusively in terms of these two objectives. ${ }^{9}$ To assist trustees in attaming these objectives, courts have also developed a hist of ten criteria for trustees to consider in selecting a particular investment. ${ }^{10}$ These "traditional" criteria focus

6. Restatement, supra note 1, \& 227. See Harvard College v. Amory, 26 Mass. 446, 461, 9 Pick. 446, 461 (1830); III A. SCoTT, supra note 1, § 227.

7. This is most easily demonstrated by reference to prohibitions-e.g., "nonproper" motives would be investments whose purposes are to benefit the trustee or a third party. See generally RESTATEMENT, supra note $1, \S 187$, Comment 2, Illustrations at 404.

8. Restatement, supra note $1, \S 187$, Comment $\mathrm{g}$ at 404.

9. See, e.g., Carlton's Estate v. Commissioner, 298 F.2d 415, 418 (2d Cir. 1962).

10. These criteria are: (1) the marketability of the particular mvestment; (2) the length of the term of the mvestment; (3) the probable duration of the trust; (4) the probable condition of the market with respect to the value of the particular investment at the termination of the trust, espe- 
the trustee's attention on the economic soundness of the investment and the needs of the trust's beneficiaries.

The controversy is over whether nontraditional objectives-e.g., social or moral goals-constitute "proper motives" and thus are permissible for trustees to foster at the expense of traditional goals. Two cases, Blankenship v. Boyle ${ }^{11}$ and Withers v. Teachers' Retirement System, ${ }^{12}$ provide very different approaches to the resolution of this issue.

\section{Blankenship v. Boyle}

Blankenship v. Boyle, decided by the District Court for the District of Columbia, provides support for the view that trustees may not pursue nontraditional objectives to the detriment of traditional investment goals.

The case involved an investment made by trustees of a union pension fund. The trustees, officials of the United Mineworkers Union, deposited the fund's assets $m$ an interest-free account in a bank owned by the union. The bank used these assets and the subsidy derived from the waived imterest on the deposits to buy controlling stock in electric utility companies. As controlling shareholder, the bank thereafter required the utilities to burn union-mined coal.

Plamtiffs challenged the trustees' decision to place the fund's assets in an interest-free account. They argued that such an investment was inherently imprudent because it could never produce an adequate return. The trustees contended, however, that this investınent was prudent, despite its failure to achieve one of the traditional investment objectives. They pointed out that the pension fund was partially supported by contributions from the coal owners on a per-ton basis. Therefore, by forcing the utilities to burn coal, the trustees were ensuring the continued support of the fund. Moreover, the investment helped to preserve umion jobs. These facts, the trustees argued, clearly nade the investment prudent.

The district court rejected the trustees' conception of prudent investimg. It determined that the utility stock acquisitions were made primarily to aid the union, rather than to benefit the pension fund. The court stated:

cially if at termination, the investment must be converted into money for purposes of distribution; (5) the probable condition of the narket with respect to reinvestment at the time when the particular investment matures; (6) the aggregate value of the trust estate and the nature of the other investmeuts; $(7)$ the reqnirements of the beneficiaries, particularly with respect to income needs; (8) the other assets of the beneficiaries including their earning capacities; (9) the effect of the investment in increasing or diminishing hability for taxes; and (10) the likelihood of inflation. Restatement, supra note $1, \S 227$, Comment o at 535.

11. 329 F. Supp. 1089 (D.D.C. 1971).

12. 447 F. Supp. 1248 (S.D.N.Y. 1978), affd, 595 F.2d 1210 (2d Cir. 1979). 
The intimate relationship between the Union's financial and organizing activities and the utility investinent activities of the trustees denionstrates that the Fund was acting primarily for the collateral benefit of the Union and the signatory operators in making most of its utility stock acquisitions. These activites present a clear case of selfdealing on the part of trustees . . . and constituted a breach of trust. ${ }^{13}$

Thus, the ruling in Blankenship arguably requires that trustees be strictly accountable for adequate return and corpus safety. Carried to its logical conclusion, the decision would sharply limit trustees' ability to promote nontraditional objectives at the expense of trust security and yield. ${ }^{14}$

\section{Withers v. Teachers' Retirement System}

More recently, the District Court for the Southern District of New York reached an apparently contrary decision in Withers $v$. Teachers, Retirement System. There, the court scrutinized a purchase of unmarketable and highly speculative bonds of the City of New York by trustees of the Teachers' Retirement Fund. Plamtiffs contended that the trustees' objective was to rescue the city from financial ruin, not to provide an adequate return or to protect the trust corpus. They argued, therefore, that the investment was clearly imprudent.

The court stated that had the city's potential bankruptcy not been a factor, the trustees' decision to commit so large a portion of the Fund's assets to the purchase of city bonds would have violated the prudent man standard. Because the trust fund would be seriously harmed were the city to go bankrupt, however, the court held that the investment was proper. It stated that

The extension of aid to the City was sinuply a means-the only means, in their [the trustees'] assessinent-to the legitimate end of preventing the exhaustion of the assets of the [Retirement Fund] in the interest of all of the beneficiaries. Notably, the importance of the solvency of the City to the [Retirement Fund] lay not only in its role as the major contributor of funds but also as the ultimate guarantor of the payment of

13. 329 F. Supp. at 1106.

14. See, e.g., RESTATEMENT, supra note $1, \$ 187$, Comment $g$ at 404 . One court, without changing this rule, has acknowledged an exception due to unusual circumstances. In In re London's Estate, 104 Misc. 372, 171 N.Y. Supp. 981 (1918), affd mem., 175 N.Y. Supp. 910 (1919), the trustee, contrary to the settlor's instructions, invested in "liberty bonds." In absolving the trustees the court held:

A strict and literal interpretation of the law . . . would require an adjudication that such investment was unauthorized. But these are abnormal times. Our country is engaged im a great war . . . Under these circumstances the court should not be bound by narrow and restricted rules of law and construction in questions which affect the welfare of our country, but should exercise its best and widest discrction. The investment by the trustees in these Liberty Loan bonds was in aid of our government in its hour of nced, and they should be commended rather than condemned therefor.

Id. at 983. 
pension benefits to participants .....15

The court then attempted to distinguish Blankenship. It reasoned that the trustees of the Teachers' Fund had considered the interests of the City of New York only because the city was an indispensable contributor of monies to the pension system. The trustees in Blankenship, on the other hand, pursued an investment policy that was intended primarily to enhance the position of the union and the welfare of its members, rather than to protect an indispensable contributor. ${ }^{16}$

This effort to reconcile Blankenship and Withers is somewhat facile. Certainly, there is little distinction between saving a city that guarantees a pension fund and protecting union jobs that serve to bolster an existing pension fund. In Withers, the court approved the mvestment because it produced a direct benefit to plan participants; in Blankenship, the court rejected such a rationale. ${ }^{17}$

Withers may represent an interpretation of the prudent man rule that is quite different fron that set fortli in Blankenship. Blankenship espouses the traditional conception of the rule: a trustee may not select an investment that fosters nontraditional objectives at the expense of adequate rate of return and corpus safety. In contrast, Withers appears to permit a fiduciary to compromise these traditional objectives in favor of the other goals-at least to some extent. The court uplield the trustees' mvestment only because the investunent gave much-needed aid to the fund's principal contributor and helped to preserve the jobs of fund participants. That is, the investment was prudent in this case because it provided "other benefits." The prudent man standard that emerges from Withers can thusly be cast: a trustee is permitted to sacrifice adequate return and corpus safety only where the investment provides "other benefits" to the interested parties.

There is some disagreement among courts about the appropriate interpretation of the prudent man standard at common law. Few cases have directly considered the legitimacy of pursuing nontraditional in-

15. Id. at 1256. A 1977 law review article foreshadowed the Withers holding in stating that "the trustee might consider [when inaking an investment] the value of preserving the jobs of future and currently vested beneficiaries, not because this maximizes their pensions but because it is clearly in their best interest to avoid demotions, layoffs, and salary cuts." Note, Public Employee Pensions in Times of Fiscal Distress, 90 Harv. L. Rev. 992, 1008 (1977).

16. Withers v. Teachers' Retirement Sys., 447 F. Supp. 1248, 1255-56 (S.D.N.Y. 1978), affd, 595 F.2d 1210 (2d Cir. 1979).

17. These cases might have reached nore consistent conclusions had the trustees in Blankenship been able to point to authority in the trust instrument for their course of action. As Professor Scott has stated, "the terms of the trust may . . . be broad enough to authorize the trustee to inake investments which a prudent man would not make. He may be authorized to invest in securities which are of a speculative character." III A. ScoTT, supra note 1, §227.14, See Gimbel v. Gimbel Found., Inc., 166 Conn. 21, 347 A.2d 81 (1974); In re Greenhouse's Estate, 338 Pa. 144, 12 A.2d 96 (1940). See generally discussion in text accompanying notes 58-63 and Part IIc2 infra. 
vestment objectives. Blankenship and Withers do speak to this issue, however, and stand for different imterpretations. Neither one is dominant at this point.

\section{B. The Rule As Viewed By Commentators}

This section examines two types of cominentary on the prudent man rule. The first is by scholars and critics of present investinent practices who argue that nontraditional objectives can be achieved without sacrificing adequate return or corpus safety. The second is an elaboration of Professor Scott's thesis in his treatise, The Law of Trusts. ${ }^{18}$

\section{Commentators Who Believe That Nontraditional Investment Objectives Can Be Achieved Without Sacrificing Adequate Return or Corpus Safety}

Many cominentators have argued that trustees and investment managers have failed to make "socially responsible" investments. ${ }^{19}$ These cominentators attribute this failure to existing investment practices. In their view, a trustee can successfully promote nontraditional investment objectives without sacrificing adequate return or corpus safety. The fault, in other words, lies not with the prudent unan standard, but with the types of investments that trustees have made under the standard. Trustees must take care to choose investinents that achieve both traditional and nontraditional objectives.

There are two versions of this arguinent. The first is that trustees have mistakenly chosen "blue chip" investments ${ }^{20}$ to the exclusion of other financially sound investments that better proinote nontraditional goals. The second is that trustees have failed to identify "enlightened" corporations for investment purposes.

Proponents of the first approach ${ }^{21}$ point out that institutional trustees typically place trust assets in "blue chip" investment vehicles. In their view, this practice makes it difficult, if not impossible, to promote social or other nontraditional goals; only a limited number of social objectives can be furthered through blue chip investunents.

The interesting fact, in these commentators' view, is that blue chip investments have frequently earned low rates of return-lower, in soine instances, than those earned by various other types of investunents these

18. III A. SCotT, supra note 1.

19. See note 2 supra.

20. The term "blue chip" investments is used here to mean stocks, bonds, and other equity and debt instruments of corporations that, over the years, have earned a reputation for providing sohd returns and safe investments.

21. E.g., J. RifXIN \& R. BARBER, supra note 2; M. Weiss \& B. Behn, supra note 2. 
commentators regard as more "socially beneficial."22 Accordingly, a trustee who inakes selective "non-blue chip" investments acts prudently; these investments produce an adequate rate of return and provide corpus safety. Moreover, the investments foster socially desirable ends that blue chip investments typically do not achieve. These commentators conclude, then, that by selecting appropriate investments as part of the portfolio, trustees can promote nontraditional goals without sacrificing adequate return or corpus safety.

This argument has difficulties. Its empirical claims are, at best, tenuous. Trustees typically place trust assets in blue chip imvestments because no other investment vehicles are perceived as achieving adequate return and corpus safety as well. ${ }^{23}$ Certainly, other investments that have achieved better results than blue chip investments can be identified with hindsight. The prudent man standard, however, does not permit hindsight judgment of investment choices-the prudence of an investment is determined at the time the trustee makes the investment, not when the results are known. ${ }^{24}$ Thus, confronted with a choice between blue chip and "non-blue chip" "investments, trustees tend to select the former in order to comply with the traditional interpretation of the prudent inan standard.

Some commentators have taken a slightly different approach. ${ }^{25}$ They recognize that large institutional trustees are understandably reluctant to venture imto questionable non-blue chip investments. They believe, however, that fiduciaries can promote social objectives even

22. M. Weiss \& B. Behn, supra note 2 , at 47.

Unfortunately, in inost cases it is considered "prudent" merely to do what everyone else does, such as invest heavily in blue-chip corporate stocks. . . . The only problem is that the average rate of return on stocks simce the late $60 \mathrm{~s}$. . . has been abysmally low compared to other types of investments.

Id. See also J. RifKIN \& R. BARber, supra note 2, at 187-88: "What about investments outside the stock inarket? [H]ome mortgages [yield] an 8 percent guaranteed return . . . . Coinpared to almost all major corporate equities and many corporate bonds, they're simply a better deal."

Some of these commentators argue that not only are traditional "prudent" imvestments not really prudent, but also that the rule itself is a ruse fostered by bank trust departments and institutional money managers. That is, the "prudent man rule" has been used as a justification for portfolio managers to turn their backs on investments in all new enterprises simce, under the rule as promulgated, it is only considered "prudent" to do what everyone else does, such as invest lueavily in blue-chip corporate stocks. J. RIFKIN \& R. BARBER, supra note 2, at 102-03; M. Weiss \& B. Behn, supra note 2, at 47-48.

23. See, e.g., Pension Fund Investment Policy: Hearings Before the Subcomm. on Citizens' and Shareholders' Rights and Remedies of the Senate Comm on the Judiciary, 95th Cong., 2d Sess. 2 (1978) (statement of Harrison V. Smith, executive vice president, Morgan Guaranty Trust Co. of New York) [hereinafter cited as Smith Statement]. See also Study Says Sponsors Are Cautious, Pensions \& INVEstMents, Sept. 12, 1977, at 54 ("Private pension plan officials have grown very cautious about investing in anything other than blue-chip securities . . . .).

24. RESTATEMENT, supra note $1, \S 227$.

25. See, e.g., Baldwin, supra note 2; B. LoNGSTRETH \& H. RosenBLOOM, supra note 2; INSTITUTIONAL INVESTOR, SUPRa note 2. 
within the confines of blue chip investinents. The fiduciary, in their view, should identify and invest in corporations that have taken "enlightened" social positions. ${ }^{26}$ These commentators argue that enlightened companies have the best long-range economic potential. ${ }^{27}$ Accordingly, such investing would not only foster social goals but would maximize the financial health of the portfolio.

This approach, however, also has difficulties. The commentators fail to articulate any criteria for classifymg corporations as "enlightened." There is ample reason for this-the concept of "enlightened" or "socially responsible" action is inherently subjective. ${ }^{28}$ Even if there were general agreement about the meaning of "enlightened" action, there are no empirical data to prove that enlightened corporations fare better than their unenlightened counterparts. ${ }^{29}$

All of these commentators correctly believe that some social objectives can be achieved without sacrificing adequate rate of return and corpus safety. It seems, however, that at some point the desire to promote nontraditional investment objectives necessarily conflicts with the

26. See, e.g., B. LONGSTRETH \& H. ROSENBLOOM, supra note 2, at 62; Baldwin, supra note 2, at 35; Institutional Investor, supra note 2, at 126. See also discussion in J. Simon, C. Power, \& J. GUNNEMAN, supra note 2, at 137-40.

27. See, e.g., Baldwin, supra note 2, at 36-37:

[A] coinpany's allegedly improper discriminatory practices may cause governments, investors and others to damage the coinpany, perhaps by selling stock, refusing einployment, denying contracts, etc. Such damage may depress the market value of the stock, and prudent investors foreseeing such a fall would be justificd in divesting that stock, wholly or partially.

28. See Malkiel \& Quandt, Moral Issues in Investment Policy, HARv. Bus. REV., MarchApril 1971, at 37, 41; Smith Statement, supra note 23, at 7.

The difficulty in determining what is a prudent socially responsible investunent can be illustrated by several examples. Thus, it can be argued that investing in FHA-insured mortgages will produce more housing, a seemingly desirable social objective. But it can also be argued that purchasing FHA-insured paper encourages the construction of poorly located and often poorly built suburban community housing. Some beheve, for exanple, that it is the ready availability of these types of dwelling units that has led to the econonic and social disintegration of this country's urban centers. See, e.g., House Comm. on Banking, Finance and Urban AfFairs, SubCOMM. ON THE CITY, 95TH CoNG., 1st SEsS., Federal. TaX Policy and URban Development 1 (Comm. Print 1977). It is difficult to conclude, therefore, that FHA investments are inore socially responsible than investments in particular private conpanies.

Another example also illustrates the dilemina. How is a trustee to evaluate the wisdom of an investment in a private company that nakes chemical substances that can only be uscd in wartine (an objective sone would view as irresponsible) although the same company produces products which increase agricultural yields and aid in the mitigation of world faninie?

29. There are, in fact, strong arguments to the contrary. Malkiel and Quandt suggest that it is only natural that one should find nuany of the most agressive U.S. corporations operating in southern Africa, because it has been the pattern for such corporations to expand their operations, if they are successful, into every ınajor foreign inarkct . . . . [I] 1 movative and growth minded coinpanies will generally want to inarket their products worldwide.

Malkiel \& Quandt, supra note 28, at 43. See also J. Simon, C. Power, \& J. GunNeman, supra note 2 , at $137-40$. 
traditional goals. The argument that trustees can effectively promote significant social objectives under the traditional interpretation of prudence is simply untenable. Thus, if trustees are to have the freedom to pursue nontraditional goals in a significant manner, courts inust be willing to permit fiduciaries to sacrifice return and corpus safety to some extent, i.e., they must accept other interpretations of the prudent man standard.

\section{The Corpus Preservation Approach}

A recent addition to Scott's The Law of Trusts ${ }^{30}$ contends that trustees should promote moral and social objectives through their investments. Professor Scott states:

In making and retaining investments, the question arises whether trustees are rigidly bound to attempt to secure the maximum return, whether as to income or principal, consistent with safety . . . .

The directors of a business corporation . . . may, within proper limits, make gifts . . . for charitable purposes . . . . So also . . . trustees have been permitted to make gifts to charity.

Trustees im deciding whether to imvest im, or to retain, the securities of a corporation may properly consider the social perfornance of the corporation. They may decline to invest in, or to retain, the securities of corporations whose activites or some of them are contrary to fundamental and generally accepted ethical principles. They may consider such matters as pollution, race discrimination, fair employment and consumer responsibility.

Of course they may well beheve that a corporation which has a proper sense of social obligation is more likely to be successful in the long run than those which are bent on obtaining the mazimum amount of profits. But even if this were not so, the investor though a trustee of funds for others, is entitled to consider the welfare of the coininunity, and refram from allowing the use of the funds in a manner detrimental to society. ${ }^{31}$

Scott justifies this position by reference to corporate charitable contributions. ${ }^{32}$ He notes that corporations may make gifts to charities "within proper limits." The rationale for this proposition is that by aiding society as a whole, the corporation furthers its own long-term interests. Similarly, a trustee arguably should be able to promote social objectives through his or her investments on the theory that this aids

30. III A. Scott, The Law of Trusts (3d ed. Supp. 1978).

31. Ill A. ScotT, supra note 30, § 227.17. It is interesting to note that Scott offers no rationale for this proposition and merely presents it as a statement of law. Few authorities are provided, and references to Blankenship and Withers are conspicuously missing. Nevertheless, because of its source, this position may well carry significant weight.

32. See discussion of the Uniform Management of Institutional Funds Act at Part ID infra. 
society and thereby strengthens the foundation of the trust. Scott, however, notes that he would place "proper limits" on trustee discretion. ${ }^{33}$

Professor Scott did not attempt to articulate any limitation on a trustee's discretion to promote nontraditional imvestment objectives. Nevertheless, we propose that one limitation Scott might have adopted is that the trustee must, at a minimum, preserve the trust corpus. Under such a "corpus preservation" approach, a trustee complies with the prudent man standard if his or her mvestment does not needlessly endanger the trust corpus. ${ }^{34}$ This would permit a trustee to choose an imvestment that is expected to produce a moderate or even no return.

The corpus preservation approach redefines the prudent man standard. Under the traditional imterpretation of the standard, a trustee is required to promote two objectives: attainment of an adequate rate of return and safety of the corpus. ${ }^{35}$ The corpus preservation approach deemphasizes one of these objectives-attainment of an adequate rate of return. This means a trustee must meet only the other objectiveprotection of the corpus-in order to comply with the prudent man standard. Absent the constramt of having to select each investment so that it yields an adequate rate of return, trustees would thus have considerably more freedom to pursue nontraditional objectives.

The corpus preservation approach has not yet been endorsed by any court. Its acceptability awaits judicial testing.

\section{The Employee Retirement Income Security Act}

The Employee Retirement Income Sccurity $\mathrm{Act}^{36}$ governs the creation and maintenance of private employee pension plans. Employee pension trusts created under ERISA differ in significant respects from coinmon law trusts. For example, pension trusts are perpetual; personal trusts at coinmon law generally have a limited duration. Pension trusts are generally predictable with respect to contribution and distribution; ${ }^{37}$ coinmon law trusts are not. Finally, ERISA trusts are free

33. III A. ScotT, supra note $30, \S 227.17$.

34. See Goldstein, The Legality of the Southern African Divestment Policy of the State Board of Higher Education 8-9 (n.d.) (unpublished study prepared on behalf of People for Southern African Freedom and Clergy and Laity Concerned).

35. See note 1 supra.

36. 29 U.S.C. § 1001 ef seq. (Supp. IV 1974).

37. Committee on Investments by Fiduciaries, Probate and Trust Division, ABA Section of Real Property, Probate and Trust Law, Fiduciary Responsibility and the Employce Retirement Income Security Act of 1974, 12 ReAL PROP., Probate \& TRUST J. 285, 297 (1977) [hereinafter cited as Committee on Investments].

We note that many collectively bargained trusts base their contributions on some external standard-e.g., per ton of coal mined. Thus, as changes in the industry occur, the predictabihty of the contributions may decrease. 
from all taxes. ${ }^{38}$ Long-term planning is therefore possible with ERISA trusts and no overriding impediments would appear to foreclose frequent changes in mvestments. ${ }^{39}$

The Act sets out its own "standards of conduct, responsibility, and obligation for fiduciaries of employee benefit plans": ${ }^{40}$

Sec. 404(a)(1) . . . [A] fiduciary shall discharge his duties with respect to a plan solely in the interest of the participants and beneficiaries and-

(A) for the exclusive purpose of:

(i) providing benefits to participants and their beneficiaries; and

(ii) defraying reasonable expenses of administering the plan;

(B) with the care, skill, prudence, and diligence under the circumstances then prevailing that a prudent man acting in a like capacity and familiar with such matters would use in the conduct of an enterprise of a like character and with like aims;

(C) by diversifying the investments of the plan so as to minimize the risk of large losses, unless under the circumstances it is clearly prudent not to do so; and

(D) in accordance with the documents and instruments governing the plan insofar as such documents and instruments are consistent with the provisions of this title.

The fiduciary responsibility section of the Act codifies and nnakes generally applicable to pension trusts the principles of fiduciary duty developed at common law. ${ }^{41}$ ERISA's prudent man rule, however, differs in a few respects froin its common law counterpart.

One difference is that ERISA requires a fiduciary to exercise a higher degree of skill and care than that demanded at common law. Under the common law standard, a fiduciary must exercise such skill and care as would a prudent man, or such skill and care as the fiduciary

38. I.R.C. $\$ 501(a)$.

39. Committee on Investments, supra note 37, at 297. For example, the fact that all pension imcome is free from taxation while in the trust and is taxed to beneficiaries at ordinary rates when distributed, regardless of the source, should free fiduciaries froin the need to account for tax considerations that restrict the investment decisions of trustees of common law trusts. In addition, private pension plans, unlike private trusts which usually receive funding only at their creation, obtain new funds on a regular basis, thereby easing liquidity considerations that would otherwise require frequent investment decisionmaking. See Note, Fiduciary Standards and the Prudent Man Rule Under the Employee [sic] Retirement Income Security Act of 1974, 88 HARV. L. REV. 960, 968 (1975).

40. ERISA \& 2(b).

41. H.R. Rep. No. 533, 93d Cong., Ist Sess. 13 (1973), reprinted in II SubCOMM. ON LABOR of the Senate Comm. on LaB. \& Pub. Welfare, 94Th Cong., 2D Sess., Legislative History OF THE EMPLOYEE RETIREMENT INCOME SECURITY ACT OF 1974, at 2360 (1976) [hereinafter cited as ERISA LEgISLATIVE HiSTORY]; 120 CoNG. REC. 29945 (1974), reprinted in III ERISA LegISLATIVE History 4781; 120 CoNG. REC. 3982 (1974), reprinted in II ERISA LEgISLATIVE HistoRY 3308. 
has or claims to have. ${ }^{42}$ In contrast, an ERISA trustee must exercise the skill and care that a prudent man, acting in a like capacity and familiar with such matters, would use in conducting an enterprise of like character and aims. Thus the "prudent man" agamst which courts will judge the ERISA fiduciary will usually be a trustee accustomed to the management of large funds. In effect, the Act requires the ERISA trustee to act as a prudent expert. ${ }^{43}$ In interpreting this requirement, courts will probably look to the procedures of successful fund managers. ${ }^{44}$

Some commentators argue that a second difference between the two standards is that the ERISA prudent man rule permits a fiduciary to place more emphasis on the performance of the overall portfoho than on the performance of individual investments. ${ }^{45}$ Under the common law standard, courts generally assess the prudence of a particular investment without looking to the entire portfolio. ${ }^{46}$ This forces a trustee to ensure that each investment meets the two traditional objectives-preservation of the trust corpus and adequacy of return. Under the ERISA standard, trustees will probably be able to take somewhat greater risks on individual investments if they have balanced these selections with safer choices in the remainder of the portfolio. ${ }^{47}$

An important question is whether trustees will be able to promote nontraditional mvestment objectives under ERISA at the expense of adequate return and corpus safety. At first glance, the Act appears to sharply limit the trustee's freedom to foster nontraditional goals. The mclusion in the ERISA fiduciary rule of the phrases "solely in the interest" and "exclusive purpose of providing benefits" suggests that courts may not permit trustees to stray from traditional investment precepts. These two provisions have served to make imvestment managers reluctant to pursue nontraditional objectives through their invest-

42. Restatement, supra note $1, \S 174$; III A. SCOTt, supra note $1, \S 227.2$.

43. Committee on Investments, supra note 37, at 297.

44. Id. at 297-98. That is not to say, however, that investment managers of small funds must apply exactly the same techniques as managcrs of large funds. Presumably the techniques inay vary, but not the inore abstract level of care that is required. 44 Fed. Reg. 37,221, 37,224 (1979) (to be codified in 29 C.F.R. \& 2550.404a-1).

45. "It is my position, and the position of the Labor Department, that under . . . ERISA the prudence of any investment for a pension plan should be judged in relation to the role which the proposed imvestment is to play in the portfoho . . . ." B. MARCUS, THE PRUDENT MAN 34 (1978). See Belliveau, Searching for a Prudent Man, 12 Institutional Investor 33, 38 (1978); Note, supra note 39, at 973. But see Spitzer v. New York, 35 N.Y.2d 512, 323 N.E.2d 700 (1974).

46. III A. ScotT, supra note $1, \S 227$. The portfoho as a whole is considered only to test whether there is sufficient diversification to minimize the risk of loss. G. BOGERT, HANDBOOK OF THE LAW OF TRUSTS § 106 (5th ed. 1973). See In re Dreier's Estate, 204 Wis. 221, 235 N.W. 439 (1931).

47. See Note, supra note 39 , at $973-79$. 
ment decisions. ${ }^{48}$

This reluctance may be unwarranted. The "solely in the interest" provision of ERISA constitutes nothing more than a restatement of the common law duty of loyalty. ${ }^{49}$ As such, this provision should have no impact on trustees who promote nontraditional objectives through their investments. The purpose of the duty of loyalty is to require a fiduciary to avoid situations where his or her own interests are at odds with those of the beneficiaries. ${ }^{50}$ As long as the fiduciary avoids self-interested transactions, his or her investment decisions should not be subject to attack under this provision.

Additionally, the requirement that the fiduciary discharge his or her duties "for the exclusive purpose of providing benefits" should not pose an absolute obstacle to the promotion of nontraditional investment objectives. This provision has several possible interpretations. ${ }^{51}$

48. B. MARCus, supra note 45 , at 3.

Some policymakers lave discovered that-absent specific authorization-pension fund trustees are increasimgly unwilling on "lack of prudence" grounds, to make certain types of risk-oriented investments. In response, Senator Bentsen of Texas introduced a bill that would have modified the prudent man rule of ERISA to allow two percent of the assets of a covered pension fund to be invested in smaller companies that might not normally fall within the "prudent investment" rubric. Pension Simplification and Investment Rules: Joint Hearings on S. 285 and S. 901 Before the Subcomm. on Private Pension Plans and Employee Fringe Benefits of the Senate Comm. on Finance and the Select Comm. on Small Business, 95th Cong., 1st Sess. 12 (1977).

Similarly, Senators McIntyre of New Hampshire and Nelson of Wisconsin introdnced S. 1745 , which provided that a fiduciary could, in meeting his purpose, consider "the long term, taking account of the necessity of improving the productivity of the economy of the United States and its international competitiveness and its capacity to snstain the real incone value of future retirement benefits to beneficiaries of the plan." S. 1745, 95th Cong., 1st Sess. \$ 9 (1977). Under the Labor Department's recently adopted prudence regulations, 44 Fed. Reg. 37,221 (1979) (to be codified in 29 C.F.R. $\$ 2550.404 a-1)$, the above types of investments would appear to be acceptable. However, this new regulatory flexibility seems to conflict with the opimion of the current ERISA Administrator, who has indicated that such investments are permissible only if acceptable under traditional criteria. Pension Fund Investment Policy: Hearings Before the Subcomm. on Antitrust, Monopoly, and Business Rights of the Senate Subcomm. on the Judiciary, 96th Cong., 1st Sess. 2 (1979) (statement of Ian Lanoff, Administrator, Pension and Welfare Benefit Programs, Dep't of Labor) [hereinafter cited as Lanoff Statement].

49. As set forth in the congressional debates on ERISA, the purpose of this language was to place a duty on every fiduciary "to act solely in the interest of the participants and beneficiaries of the plan; that is, to refrain from involving himself in situations or transactions (especially transactions with known parties in interest) where his personal interests might conflict with the interests of the participants and beneficiaries for whom the fund was established." 119 CoNG. REc. 12,076 (1973) (statements of Senator Javits), reprinted in I ERISA LEGISLATIVE HISTORY, supra note 41, at 27576 (emphasis added). See also Report, ERISA and the Investment Management and Brokerage Industries: Five Years Later, 35 Bus. LAw. 189, 232 (1979); Hutchinson \& Cole, Legal Standards Governing the Investment of Private Pension Capital, in 27, 55-56 (1980); Ferguson, Social Investing: An Advocate's Perspective, EMployed Benefits Research INSTITUTE, Should Pension ASSets Be Managed for Soclal/Political Purposes? 94, 97 (1980).

50. "It is the duty of a trustee to administer the trust solely in the interest of the beneficiaries. He is not permitted to place himself in a position where it would be for his own benefit to violate his duty to the beneficiaries." III A. ScoTT, supra note $1, \S 170$.

51. Thus, one approach to this language is merely to consider it as an additional restatennent 
All of them appear to permit a trustee to incorporate nontraditional objectives into his or her investınent decisionmaking. A sensible limitation on this discretion, however, may be derived from the statute. The requirement that the investment be for the purpose of providing benefits seems to mandate that a tangible gam must be realized. The concept of "benefits," however, need not be limited to payments that a participant or beneficiary would receive upon retirement, i.e., pure economic return to an mvestment. It is arguably broad enough to include numerous types of positive returns, e.g., job security and improved working conditions. Thus, this provision can be construed to allow a

of the trustee's duty of loyalty. Report, supra note 49, at 232. As such, it would supplement the "solely in the interest" restriction. If that is in fact the case, then the analysis in text accompanying note 48 supra, applies and there is no limitation on the cousideration of nontraditional goals.

A second interpretation of this language is to view it as not referring to imvestments. Rather, this section might be construed so as to refer only to the way in which the plan is to be administered, i.e, the expenditures of all funds, not including investments, must be for the exclusive purpose of furthering the interests of the participants and beneficiaries. Hutchinson \& Cole, supra note 49, at 70. This interpretation, thus, breaks down the common law duty of loyalty in ERISA between the "solely in the interest" language, which refers to the duty of loyalty in investments, and the "exclusive purpose of providing benefits" language, which goes to the duty of loyalty in administration. There is some support for this interpretation in the legislative history which provides that not only inust a fiduciary act as a prudent man but he must "act consistently with the principles of administering the trust for the exclusive purposes . . . enumerated . . . " S. REP. No. 93-127, 93d Cong., lst Sess. 30 (1973), reprinted in I ERISA LEGISLATIVe HISTORY, supra note 41 , at 587,616 .

In contrast, a third interpretation would require that the tenn "benefits" imclude retirement benefits. Despite the prior cited language which indicates that the "exclusive purpose of providing benefits" language is aimed at the administration of the fund, there is other congressional language that also supports the proposition that, in fact, this standard was meant to apply to imvestinents.

Under the Internal Revenue Code, qualified retirement plans inust be for the exclusive benefit of the employees and their beneficiaries. Following this requirement, the Internal Revenue Service has developed general rules that govern the investment of plan assets .... The conferees intend that to the extent that a fiduciary meets the prudent man rule of the labor provisions, he will be deemed to meet these aspects of the exclusive benefit requirements under the Interual Revenue Code.

H.R. REP. No. 93-1280, 93d Cong., 2d Sess. 302 (1974), reprinted in III ERISA LegisLATIVE HistoRY, supra note 41, at 4277, 4569 (empliasis added).

See Rev. Rul. 73-380, 1973-2 C.B. 124, which establishes four guidelines which must be met if an investment is to be considered within "the exclusive benefit" requirement: (1) the cost must not exceed fair inarket value at the time of purchase; (2) a fair return commensurate with the prevailimg rate inust be provided; (3) sufficient hiquidity inust be maintained by the trust to permit distributions in accordance with the terms of the plan; and (4) the safeguards and diversity that a prudent investor would adhere to must be present.

We submit, however, that even if the "exclusive purpose of providing benefits" language is deemed to apply to investment decisions, no authority requires that this language be interpreted to apply exclusively to retirement benefits. Indeed, the language relating the ERISA standard to the Internal Revenue standard indicates that as long as an investment ineets the test of prudence, the investment will be considered as for the exclusive benefit of the participants and beneficiaries. However, it inust be noted that while "comphance with ERISA Section 404(a) would . . . result in compliance with the general rules set by the IRS for determining whether a plan is for the exclusive benefit of the employees and their beneficiaries, ... . [they] conspicuously reframed from stating the converse ...." Report, supra note 49, at 234. 
trustee to promote nontraditional objectives at the expense of adequate return and corpus safety if the investment produces a direct "other benefit."

This broad reading of the permissible objectives of the pension trustee's duties finds support in another portion of the ERISA rule that requires a fiduciary to act solely in the interests of the "participants and the beneficiaries." 52 The word "participant," as defined by the statute, includes not only retired persons, but also active workers and contributors to the pension fund..$^{53}$ Beneficiaries are those designated by participants to receive benefits ${ }^{54}$-most commonly dependents. The statute, by distimguishing between those receiving payments and active workers, can be construed to grant a fiduciary the authority to invest in order to aid current employees who are participating in the plan as well as retirees and beneficiaries. ${ }^{55}$ This would permit the fiduciary to promote nontraditional objectives-such as job security-at the expense of corpus safety and adequate rate of return.

So interpreted, this statutory language--ERISA's version of the prudent man rule-may be the equivalent of the Withers standard. In Withers the court upheld a pension fund investment that the trustees beheved was necessary to further the welfare of all of the fund's members. $^{56}$ Under this interpretation, any reasonable investment that provides direct benefits for the participants-even if it does not necessarily yield an adequate economic return-would be permissible. ${ }^{57}$

52. ERISA § 404(a)(1) (emphasis added).

53. "The term 'participant' means any employee or former employee, or any member or former member of an employee organization, who is or may become eligible to receive a benefit of any type ...." ERISA \$ 3(7).

54. ERISA $\S 3(8)$.

55. See Lanoff Statement, supra note 48 , at 2.

56. Recall that the Withers court upheld a public pension fund investment in municipal bonds that normally would not liave been considered "prudent." The trustees felt that the investment was necessary to protect the city, a major contributor, and further the status of all of the fund's members.

The trustees were unanimously of the view that their fiduciary obligation was to safeguard the imterests of all of the members of the [Retirement Fund]-those still in active service and therefore dependent upon the long-term viability of the fund for their retirement incomes, as well as those already retired.

Withers v. Teachers' Retirement Sys., 447 F. Supp. 1248, 1252 (S.D.N.Y. 1978), aff $d$, 595 F.2d 1210 (2d Cir. 1979).

57. The legislative history of ERISA supports this propositon. The current prudent man rule was chosen in lieu of a requirement that "a fiduciary shall discharge his duties . . . in such a manner as not to jeopardize any income or assets of the fund . . .." S. 1179, 93d Cong., 1st Sess. $\$ 501(c)(1)(B)$ (1973), reprinted in, I ERISA LEgISLATIVE HISTORY, supra note 41, at 949; 119 CONG. REC. 30138 (1973), reprinted in II ERISA LEGISLATIVE HISTORY, supra note 41, at 1727. See also Culinary Workers \& Bartenders Union No. 596 Health \& Welfare Trust v. Gateway Cafe, Inc., 91 Wash. 2d 353, 363, 588 P.2d 1334, 1341 (1979).

Note, however, that a Department of Labor official has recently questioned this approach: While [section 404(a)] does not exclude the provision of incidental benefits to others, the 
Another provision in ERISA's prudence standard may have some bearing on a trustee's freedom to promote nontraditional goals. Section 404(a) of the Act requires a fiduciary to discharge his or her duties not only as a "prudent man" but also "in accordance with the documents" establishing the trust. These simultaneous requirements pose an important question: What are the consequences of a trust instrument that clearly authorizes (or even requires) investments im, for example, low-income housing, minority businesses, or environmentallyoriented ventures? In particular, is the prudence of the investment to be determined, at least in part, by the document's authorization? Or does the rule of prudence imstead set forth one standard applicable to all investments and against which the fiduciary must always weigh his or her choices regardless of the trust document's authorization? If the latter view is correct, any authorization for imvestments in the trust imstrument could be considered an "exculpation," and, therefore, void under section 410(a) of the Act. ${ }^{58}$

Courts have not addressed this issue, and it is by no means easy to resolve. ${ }^{59}$ Nevertheless, there is support for the argument that trustees

protection of retirement income is . . . the overriding social objective governing the investment of plan assets.

....

It is not consistent with the prudence standard for the fiduciary to make his or her investment decision based on other objectives, such as to promote the job security of a class of current or future participants.

Lanoff Statement, supra note 48, at 4-5.

Nevertheless, the Department of Labor has recently refused to invalidate investments in nonincome producing assets which may result in long-term fund appreciation. Such investmcnts would appear to offer more benefits to participants and less to retirees and beneficiaries. See 44 Fed. Reg. 37,221 (1979) (to be codified in 29 C.F.R. $\$ 2550.404 a-1$ ).

58. ERISA $\S 410$ (a) provides: "[A]ny provision in an agreement or instrument which purports to relieve a fiduciary from responsibility or liability for any responsibility, obligation, or duty under this part shall be void as against public policy."

59. ERISA $\$ 410$ (a) itself poses the difficulties inherent in this issue:

It is submitted that the rule of prudence is an objective standard, a standard of care, properly applicable within the boundaries set by the plan. In this regard it is to be noted that ERISA $\S 404$ (a) . . . relates to the discharge of fiduciary duties. Insofar as the design of the plan is not a fiduciary function, the rule of prudence is mapplicable to the constitution of its provisions, and the fiduciary is bound to follow its terms under ERISA $\S 404(\mathrm{a})(1)(\mathrm{D})$.

....

. . . [T] he Congressional history, reflecting a particular concern for the undesirable consequences of exculpation in the benefits context, undoubtedly evidences a belief that some fixed and absolute standard should appertain to employee benefit plans. An illustrative example of this viewpoint is provided by Rev. Rul. 73-532 . . . which held that a trust authorizing speculative and 'adventurous' investments was not for the exclusive benefit of employees.

[1979] 1 Pension \& Profit Sharing (P-H) If 20,273.

Rev. Rul. 73-532, 1973-2 C.B. 128 represents a clear example of when the overriding prudent man requirements will prevail over the trust document. In that case, the trust provided that the trustee could invest "without regard to whether investments may be new, speculative, hazardous, adventurons, or productive of income." 
should be able to consider the trust authorization in their investınent decisions. ERISA's fiduciary standard is based on the common law, ${ }^{60}$ which has always held that "prudence" is in part ineasured by trust document instructions. ${ }^{61}$ And in a 1970 Revenue Ruling, the Internal Revenue Service upheld the tax-exempt status of a trust whose amended document allowed the trustee to make investments serving "social purposes" even though they provided a lower rate of return than typical blue chip investments. ${ }^{62}$

Applied to ERISA, this reasoning would permit einployers and unions to structure pension plans to further the goals they favor. Thus, creators of a pension plan could mandate a lower rate of return on at least some investments provided that the investments benefited the plan's participants in other ways. The fiduciary would be required to follow the trust document's directives so long as he or she could defend his or her action as "prudent." Certainly, the more direct the "other benefits," the more readily a court would uphold the trustee's action.

In order to permit a fiduciary to act prudently, plan creators should guard against complete elimination of trustee discretion. That is, the document should not compel a trustee to inake or avoid specific mvestments. Such detailed instruction might place trustees in an untenable position, forcing them either to act imprudently in a particular situation $^{63}$ or to ignore entirely the directives of the governing trust document. Creators of trust plans, therefore, should frame their instructions to provide trustees with adequate latitude to achieve the

60. See note 41 and accompanying text supra.

61. G. BoGERT, supra note 46 , at $\S 102$.

62. Rev. Rul. 70-536, 1970-2 C.B. 120, considered the question of whether an amendment to an unemployment benefit trust permitting low-risk, income-producing investments that served social purposes would affect the tax-exempt status of the trust. The IRS, upholding the trust's taxexempt status, noted that

Although the proposed amendment expands the factors that may be considered by the trust in formulating its investment policy, the amendment does not affect the purpose of the trust . . . low-risk investments that produce income and also serve a social purpose will not be considered a diversion of the corpus or income from the trust's purposes even though such investments yield a rate of return lower than that in the current market. (emphasis added).

63. According to one commentator, this does not differ greatly from actual practice.

The second point against interfering with pension trustees' best judgment of how to protect their assets' availability for retirement security is that several generations of experieuce have shown the unwisdom of freezing into law any directions-other than the fiexible, general standard of prudence-about what to include or exclude in large portfohos.

. . . And most funds already try to exclude investments that are inconsistent with their sponsors' and beneficiaries' social goals. For example, I cannot imagine any joimtly-trusted fund today owning any shares of so blatant a law-breaker as J.P. Stevens.

Pension Fund Investment Policy Hearings Before the Subcomm. on Citizens' and Shareholders' Rights and Remedies of the Senate Comm. on the Judiciary, 95th Cong., 2d Sess. 20-21 (1978) (statement of Roy A. Schotland). 
nonecomonic objectives sought by the trust's creators without ignoring basic financial constraimts.

In conclusion, ERISA's prudent man standard can be construed to permit trustees to pursue nontraditional investment objectives to the detriment of traditional goals. The trustee must show, however, that the investment has resulted in "other benefits" for the plan's participants and beneficiaries if it is to be upheld as prudent.

\section{The Uniform Management of Institutional Funds Act}

The Uniform Manageinent of Institutional Funds Act, approved in 1972 and adopted in twenty-five jurisdictions since then, ${ }^{64}$ applies only to mstitutions that are organized and operated exclusively for educational, religious, charitable, or other eleemosynary purposes. It provides broad imvestment powers to governing boards of qualifying institutions, freemg these boards from investment restrictions that imhibit the fiduciaries of ordmary trust funds. Thus,

[i]n addition to an investment otherwise authorized by law or by the applicable gift instrument, and without restriction to investments a fiduciary may inake, a governing board, subject to any specific limitations set forth in applicable gift instrunent or in the applicable law other than law relating to investments by a fiduciary, may:

(1) invest and reinvest an institutional fund in any real or personal property deemed advisable by the governing board, whether or not it produces a current return, including mortgages, stocks, bonds, debentures and other securities of profit or nonprofit corporations, shares in or obligations of associations, partnerships, or individuals, and obligations of any government or subdivision or instrumentality thereof 65

The standard of care required of a fiduciary is that of the reasonable and prudent director of a nonprofit corporation-a standard like that required of the director of a busmess corporation. ${ }^{66}$ The drafters

64. The Act has been adopted in California, Colorado, Connecticut, Delaware, Illinois, Kansas, Kentucky, Louisiana, Maryland, Massachusetts, Michigan, Minnesota, Montana, New Hampshire, New Jersey, North Dakota, Ohio, Oregon, Rhode Island, Tennessee, Vermont, Virginia, Washington, Wisconsin, and the District of Columbia. See generally 7A U.L.A. 405 (1978).

65. UNIFORM MGT. OF INSTIT. FUNDS ACT $\$ 4$ (einphasis added).

66. UNIFORM MGT. OF INSTIT. FUNDS ACT, Commissioners' Prefatory Note, reprinted in 7A U.L.A. 405, 407 (1978). As set forth by the Commissioners:

The section establishes a standard of care and prudence for a member of a governing board. The standard is generally comparable to that of a director of a business corporation rather than that of a private trustee, but it is cast in ternis of the duties and responsibilities of a manager of a nonprofit institution.

UNIFORM MGT. OF INSTIT. Funds ACT $\$ 6$, Commissioners' Comment.

It las been suggested that this standard applies to endowment funds even without the Uniforn Act. W. Cary \& C. Bright, The Developing Law of Endowment Funds: "The Law AND THE LORE" REVISITED 2 (1974) ("Where the issue involved is one of administration, particu- 
of the Uniform Act believed that this standard was more appropriate than the traditional common law prudent man standard for "unique and perhaps very large" educational institutions and churches. ${ }^{67}$ They reasoned that fear of liability of the sort that may be imposed on private trustees might "liave a debilitating effect upon members of governing boards, who are often uncompensated public-spirited citizens." 968

If the drafters of the Uniform Act intended, however, to provide more investment leeway to certain fiduciaries-presumably including the authority to pursue nontraditional objectives-they did not clarify the boundaries of this discretion. Nor has any court addressed this issue.

Nevertlieless, some general primciples to assist fiduciaries of eleemosynary imstitutions im making investment choices may be distilled from case law and statutes pertaining to the right of corporations to make charitable contributions. These authorities establish that limited amounts of charitable contributions by corporations may be justified on grounds that the corporation furthers its own long-term interests by aiding society as a whole. ${ }^{69}$ The more closely related these contributions are to the actual activities or geographic location of the donor corporation-i.e., the clearer the nexus between contributions and corporate interest-the easier it is to justify the contributions.

Three cases support the view that charitable contributions by corporations are legitimate if the contributions further corporate interests. In A.P. Smith $M f g$. Co. v. Barlow, ${ }^{70}$ a corporation sought a declaratory judgment as to the propriety of its donation of $\$ 1,500$ to a private university. In upholding the donation, the court stated:

It seems to us that just as the conditions prevailing when corporations were originally created required that they serve public as well as private imterests, modern conditions require that corporations acknowledge and discharge social as well as private responsibilities as members of

larly financial administration, courts uniformly tend to apply the unore flexible principles found in corporate law.").

67. UNIFORM MGt. of INSTIT. Funds ACT, Commissioners' Prefatory Note, supra note 66, at 409 .

68. Fear of liability of a private trustee may have a debilitating effect upon members of a governing board, who are often uncompensated public-spirited citizens. They are managers of nonprofit corporations, guiding a unique and perhaps very large institution. The proper standard of responsibility is more analagous to that of a director of a business corporation than that of a professional private trustee. The Act establishes a standard of business care and prudence in the context of the operation of a nonprofit institution.

UNIFORM MGT. OF INSTIT. Funds ACT, Commissioners' Prefatory Note, supra note 66.

69. See 6A W. Fletcher, Cyclopedia of the LaW of Private Corporations $\$ 2938$ (rev. pern. ed. 1968).

70. 13 N.J. 145, 98 A.2d 581, appeal dismissed per curiam, 346 U.S. 861 (1953). 
the communities within which they operate. ${ }^{71}$

The court stated further that corporations should be allowed to make contributions "to insure and strengthen the society which gives them existence and the means of aiding themselves . . . ."72

Shlensky v. Wrigley ${ }^{73}$ relied on a similar premise to validate a corporate decision that did not maximize profits. Mmority shareholders of a corporation that owned a baseball club challenged the decision of the board of directors not to install lights im the stadium. Without highting, of course, the club could not play night games, and it was well established that night gaines were nore profitable than day games. The corporation justified its decision on the ground that night games would have a negative impact on the surrounding neighborhood. In uploolding the Board's decision, the court said:

[I]t appears to us that the effect on the surrounding neighborhood might well be considered by a director who was considering the patrons who would or would not attend the games if the park were in a poor neighborhood. Furthermore, the long run interest of the corporation in its property value . . . might demand all efforts to keep the neighborhood from deteriorating. ${ }^{74}$

Finally, in Union Pacific Railroad v. Trustees, Inc., ${ }^{75}$ shareholders contested a $\$ 5,000$ contribution to a nonprofit charity. The court upheld the donation and noted: "[I]f [the donation] were inade with the studied and not unreasonable conviction that it would benefit the corporation, it should be the type of thing that slould rest in the sound discretion of nuanagement . . .."76

The holdings in Smith, Shlensky, and Union Pacific were based, in part, on the rationale that the corporations were indirectly aiding themselves through their charitable contributions. ${ }^{77}$ Despite these broad holdings, corporate directors nuust nonetheless act witl "the degree of care ... which ordinarily prudent inen [proinpted by self-interest] would exercise under similar circumstances."78 Thus, courts apparently will approve corporate charitable contributions if the level of the donations is reasonable in the context of the particular donor corpora-

71. Id. at 154,98 A.2d at 586 .

72. Id. at 161,98 A.2d at 590 .

73. 95 III. App. 2d 173, 237 N.E.2d 776 (1968).

74. Id. at $180-81,237$ N.E. $2 \mathrm{~d}$ at 780.

75. 8 Utah 2d 101, 329 P.2d 398 (1958).

76. Id. at 101, 329 P.2d at $401-02$.

77. Legislation in most jurisdictions has since broadened the right of corporations to unake charitable contributions. See, e.g., MODel Bus. CoRP. ACT ANN. §4(m); 6A W. Fletcher, supra note 69, at $\S 2939$.

78. G. HoRnstein, Corporation LaW and Practice $\$ 446$ (1959) (quoting a formulation recommended by the Commissioners on Uniform State Laws). 
tion. ${ }^{79}$ If, however, the amount of these contributions is significant when compared to the busmess activities of the entity, compliance witlr the rule of prudence may require a slowing of greater self-interest and benefit to the corporation. ${ }^{80}$ These principles inay apply, by analogy, to the investment practices of institutions governed by the Uniform Act. To the extent that fiduciaries use institutional funds to undertake limited charitable activities, their actions will probably be viewed as prudent. But slould these endeavors grow in scope and reduce not only achievable current return, but also long-term portfolio growth, fiduciaries will lrave to justify these activities as in the self-imterest of the institution. ${ }^{81}$

\section{E. Summary}

This section has demonstrated that the prudent man rule is not a unitary concept. Indeed, there are a variety of ways to interpret the rule, many of whicli permit a sacrifice of adequate return and corpus safety in order to promote nontraditional objectives. The problem, of course, is that there is little established legal precedent on this subject. Trustees are understandably wary of openly venturing into the uncharted territory of "socially responsible" investing. Nevertheless, sensible guidelines do exist. The critical task is to organize the various interpretations of the prudent man rule into an analytic framework and indicate to trustees the range of options that they may have with respect to the pursuit of nontraditional investment goals.

79. For one possible guideline, see I.R.C. $\S 170(b)(2)$, which limits deductions for corporate contributions to charity to five percent of taxable income.

80. Although 48 jurisdictions have given business corporations the power to make donations to charity, the board of directors should use good judgment in the exercise of the power. Donations should be reasonable in amount in the light of the corporation's financial coudition, bear soine reasouable relation to the corporation's interest, and not be so "remote and fanciful" as to excite the opposition of shareholders whose property is being used. Direct corporate benefit is no longer necessary, but corporate interest remains as a motive.

Garrett, Corporate Donations, 22 Bus. LAw. 297, 301 (1967).

See also Capital Elec. Power Ass'n v. Phillips, 240 So. 2d 133, 137 (Miss. 1970) ("[While the gifts im question are permissible] we point out that it is the duty of the officers of . . . a corporation to conserve [its] funds and resources . . . and not with a prodigal hand to lavishly spend sums of mouey which could be utilized more properly for the benefit of the stockholders.").

81. For example, in Theodora Holding Corp. v. Henderson, 257 A.2d 398 (Del. Ch. 1969), the court reviewed and upheld a $\$ 528,000$ gift to charity because (1) the gift was less than five perceut of income and was thus fully deductible, (2) the gift reduced the corporation's reserve for unrealized capital gains taxes and thereby increased the balance sheet net worth, and (3) shortterm loss of mcome was outweighed by overall benefits flowing from the gift. Id. at 405 . 
II

An Analytic Framework for the Prudent Man STANDARD

This section develops a framework to analyze the prudent man standard. It argues that there are five principal interpretations of the standard that have a bearing on whether a trustee may sacrifice return and corpus safety in favor of nontraditional goals. These interpretations can be depicted as poimts along a contimuum, arranged according to the degree of freedom each gives a trustee to foster nontraditional objectives. The section then identifies where on the continuum the common law, ERISA, and Uniforn Act trustees may be able to operate. Fimally, the section develops criteria that courts and trustees should consider in determining the extent to which trustees may permissibly foster nontraditional investment objectives.

\section{A. A Continuum of Interpretations of the Prudent Man Standard}

The principal interpretations of the prudent man standard can be depicted along a five-point contimuum:

Interpretation One: The trustee may not pursue nontraditional investment goals at the expense of adequate rate of return and corpus safety.

Interpretation Two: The trustee inay sacrifice adequate rate of return, but not corpus safety, in the pursuit of nontraditional objectives so long as the investment provides direct "other benefits" to the trust's participants and beneficiaries.

Interpretation Three: The trustee may sacrifice both adequate rate of return and corpus safety im the pursuit of nontraditional goals so long as the imvestment provides direct "other benefits."

Interpretation Four: The trustee inay sacrifice adequate rate of return, but not corpus safety, in the pursuit of nontraditional goals so long as the imvestment produces indirect "other benefits" to the trust's participants and beneficiaries.

Interpretation Five: The trustee inay sacrifice both adequate rate of return and corpus safety so long as the investment produces indirect "other benefits."

Moving along the contimuum from Interpretation One to Interpretation Five, the trustee's freedom to promote nontraditional objectives increases. Interpretation One represents the most restrictive conception of the prudent man standard, i.e., the traditional interpretation. Here, a trustee is absolutely prohibited from fostering nontraditional objectives to the detriment of traditional goals. Interpretation Two gives the trustee shightly greater freedom. Pursuant to this interpretation, the 
trustee may sacrifice adequate return on the imvestment so long as the investment produces a direct "other benefit" to the trust's participants and beneficiaries. Interpretation Three carries the logic of Interpretation Two a step further-it allows the trustee to sacrifice both return and corpus safety so long as direct benefits are produced. A major division exists between the first three interpretations and Interpretations Four and Five. The concept of indirect "other benefits" is here introduced as a limitation on trustee decisionmaking. Thus, Interpretation Four allows the trustee to sacrifice return so long as the investment results in imdirect "other benefits." More than any of its predecessors, this interpretation gives a trustee greater freedom to pursue nontraditional objectives because the trustee does not have to demonstrate that the investment produces a direct benefit. All the trustee must show is that the imvestment arguably makes society a better place in which to live, thereby indirectly benefiting the trust's participants and beneficiaries. This standard is easier to meet than the direct "other benefits" standard. Finally, Interpretation Five represents the other extreme on the continuum - the trustee can sacrifice both return and corpus safety where the investment yields some indirect benefit. ${ }^{82}$

This continuum should be useful to courts in defining the extent to which a trustee can permissibly promote nontraditional investment objectives at the expense of return and corpus safety. By placing all of the reasonable alternatives in an analytic framework, the continuum will enable courts to articulate principled limitations on the trustee's freedom to pursue nontraditional goals. For example, the continuum allows a court to determine which of the traditional objectives a trustee can sacrifice in the pursuit of nontraditional goals: both adequate return and corpus safety, only adequate return, or neither objective. Additionally, it enables a court to establish the types of benefits that an investment must produce-return and corpus safety only, or these plus "other benefits"-and whether the benefits inust be direct or indirect.

\section{B. The Range of Interpretations of the Prudent Man Standard that May Apply to Investment Trustees}

Part I explored various interpretations of the prudent man standard as applied to common law, ERISA, and Uniform Act trustees. This section analyzes these interpretations in tenns of the five fornulations of the rule designated on the continuum and determines the range

82. It is, of course, possible to conceive of many more interpretations of the prudent man standard than those described here. These five serve only to highlight the general outline of the continuum of interpretations. Moreover, there are soine interpretations that would not even fit within the continuum. For exainple, the prudent inan standard could be interpreted to permit a trustee to dissipate the trust corpus regardless of any benefit produced for the participants and beneficiaries. Because no reasonable commentators have adopted this interpretation or others like it, however, there is no apparent need to broaden the continuum to include them. 
of interpretations along the continuum that may apply to particular trustees.

\section{The Common Law}

In Part I, this Article considered two cases that interpreted the prudent man standard at common law: Blankenship v. Boyle and Withers $v$. Teachers' Retirement Fund. Read literally, Blankenship loolds that a trustee may not promote nontraditional investinent objectives at the expense of return and corpus safety. This holding corresponds precisely with Interpretation One on the continuum. Thus if Blankenship receives support im American courts, trustees will be restricted to the narrowest conception of the prudent man standard. Their ability to promote nontraditional investment objectives will be incidental to their duty to protect the trust corpus and attain an adequate rate of return.

The Withers court had a substantially different view of prudent investing. There, the court lield that the purchase of speculative bonds of the City of New York by trustees of a teachers' pension plan was prudent. The court found that the investment was made to an "indispensable contributor" to the fund who was on the verge of bankruptcy and that the investment directly benefited the plan's participants and beneficiaries. Withers thus corresponds witl Interpretation Three on the continuum; it permits a trustee to pursue a nontraditional objective-in this case, financial assistance to a necessary contributor to the trust fund-at the expense of return and corpus safety where the investment produces direct "other benefits."

In contrast to Blankenship and Withers, courts might adopt the "corpus preservation" approach as the proper interpretation of the prudent man rule at common law. Under this approach, an investment is prudent so long as it meets just one of the traditional investment objectives-corpus safety. This approach, in other words, frees trustees from the constraint of having to attain an adequate return, thereby giving them considerable leeway to promote nontraditional objectives. The approach does not define how direct the benefits of an investment must be. Thus, it permits a trustee to look to Interpretation Two on the continuum-where the trustee can sacrifice return if the imvestment provides direct "other benefits"-or to Interpretation Four-where the trustee can sacrifice return if the investment provides at least indirect "other benefits." This approach, lowever, precludes the trustee from taking guidance from either Interpretations Three or Five, because both interpretations allow the trustee to invade the corpus.

Thus at common law, trustees may be able to operate as far up on the continuum as Interpretation Four. Obviously, more conservative trustees will be reluctant to venture too far beyond Interpretation Two in the absence of clear judicial precedent. That is, they would be will- 
ing to sacrifice only adequate return in pursuit of nontraditional objectives and, even then, only if the investment produced direct "other benefits." Nevertheless, it is possible that innovative courts, such as the Withers court, will permit trustees to exercise considerable discretion in determining whether the benefits to be derived from a particular investment inure, in fact, to the direct advantage of beneficiaries and participants.

\section{ERISA}

As with the common law trustees, ERISA trustees face great uncertainty in determining which interpretation of the prudent man standard apphes to them. The definition of a trustee's duties in ERISA's governing statute might, at first glance, seem to restrict a trustee to Interpretation One on the continuum. By construing the provisions "solely in the interest" and "exclusive purpose of providing benefits" narrowly, a court could prohibit a trustee from promoting nontraditional objectives at the expense of return and corpus safety. As demonstrated in Part I, however, these provisions need not be read so narrowly. Courts could construe them to permit the trustee to sacrifice one or both of the traditional objectives so long as the investment produces a direct benefit to those covered by the trust.

This more flexible construction of ERISA's provisions arguably would put an ERISA trustee in the same position as a common law trustee who is governed by the Withers approach, i.e., at Interpretation Three on the continuum. There is reason to believe, however, that courts might not permit the ERISA trustee to go much beyond Interpretation Two. The statute requires a trustee to provide retirement benefits under the pension plan. As a consequence, corpus safety must be an important element in the trustee's investment strategy. A court would probably be reluctant to permit a trustee to sacrifice the trust corpus for a nontraditional objective, however compelling that objective may be. The sensible ERISA trustee is thus well advised to promote nontraditional objectives only at the expense of return, i.e., to remaim close to Interpretation Two on the continuum.

\section{The Uniform Act}

Trustees who operate under the Uniform Act share the same dilemma as their common law and ERISA counterparts-the uncertainty under existing law of the extent to which they can promote nontraditional investment objectives at the expense of return and corpus safety. Uniform Act trustees, in fact, may be in a inore difficult position. The Act can be reasonably construed to permit them to occupy any of the five principal points on the continuum, i.e., a court could choose any one of the five interpretations to apply to the Uniform Act trustee. For 
example, if the court decided that the prudent man standard under the Act should be the same as the standard that applies to a corporate director who makes charitable contributions, the trustee would in effect be at Interpretation Five on the contimuum. At this position, the trustee would have the greatest freedoun to promote nontraditional investment objectives. It is probable, however, that a court would interpret the Act to give a trustee far less leeway to promote such goals. Thus, Interpretations One through Four are also distinct possibilities for the prudent man standard.

This uncertaimty will, predictably, cause conservative trustees to be reluctant to venture far beyond Interpretation Two on the continuum. Again, however, courts unay permit trustees to exercise more discretion in utilizing resources to promote goals desired by the institution.

\section{Factors That Will Determine a Trustee's Freedom to Promote Nontraditional Objectives}

A central theme of this Article has been the uncertamty that trustees face in determining the extent to which they can promote nontraditional investment objectives at the expense of return and corpus safety. There are, however, three factors that will clearly have a significant bearing on a trustee's freedom to promote nontraditional goals: the type of trust, the authorization in the trust document, and the provision of "other benefits." By focusing on these three factors, trustees can greatly reduce the uncertainty inherent in their investment decisions.

\section{The Type of Trust}

The type of trust that a fiduciary manages will affect his ability to pursue nontraditional goals. This Article has examined three types of trusts: common law, ERISA, and Uniform Act trusts. The standard of prudent investing under each of these trusts is not entirely clear, but it should be apparent that the standards are not identical. For exaniple, the statutory language of ERISA differs considerably from the provisions of the Uniform Act in defining prudent investing; Umform Act trustees would appear to have much greater leeway than their ERISA counterparts to pursue nontraditional objectives. Thus, all trustees should be keeuly aware of the prudent man standard that governs their trusts and the case law that gives meaning to that standard.

\section{Authorization in the Trust Document}

The instructions that a trust creator places in the trust document will be instrumental in determining the trustee's freedom to promote nontraditional objectives. Trust creators have authority to determine permissible areas of investment. Absent exphcit permission to pursue nontraditional objectives in the trust document, a trustee may have dif- 
ficulty convincing a court that his decision to sacrifice adequate return or corpus safety was prudent. On the other hand, where the trust document authorizes a trustee to pursue nontraditional goals, the trustee should have fewer fears that his or her decision to do so will be found imprudent. Indeed, a trustee who fails to comply with such trust instructions risks violating the prudent man standard.

Trust creators must carefully draft the authorizing instructions in order to imsulate trustees froin attack. The trust document should contain specifie instructions on these two points: the nontraditional goals that a fiduciary is to promote through investments and the extent to which the fiduciary nay permissibly impinge upon the traditional investment objectives in order to achieve those goals.

\section{The Provision of "Other Benefits"}

A trustee who pursues nontraditional investment goals at the expense of return and corpus safety inust provide some justification for his or her action. Clearly, an important justification is that the investment provided benefits other than return and corpus safety to the trust's beneficiaries-that the investment provided "other benefits." A trustee who can deinonstrate that his or her investincnt yielded "othcr benefits" to the trust's beneficiaries and participants will be more readily able to defend his or her actions as prudent. The more direct the "other benefits," the inore security the fiduciary has.

For example, consider a umion pension trustee who wishes to support improved housing for the umion membership through his or her investınent choices-a nontraditional goal. If that trustee invests in government housing bonds that are msured and pay market rates, e.g., Government National Mortgage Association bonds, he or she would not violate the prudent man rule, even under the most restrictive interpretation of the rule. This is because the imvestment satisfies the traditional objectives of corpus safety and rate of return. Altcrnatively, the trustee may seek to finance subsidized housing directly through participation in the developinent process. This might be accoinphished by imvestimg in long-term, low interest loans. The prudence of any such investinent is not as clear as in the first case. In evaluatimg this imvestment, which does not meet traditional investing "norms" due to a lessthan-adequate rate of return, a court would look at the investment's prospects of providing other benefits to those who have a direct stake in the pension fund. ${ }^{83}$ If those covered by the pension fund actually use the housing units, the investinent, although substantially at variance with traditional practices, would probably be sanctioned. The "other

83. See, e.g., Hemerick, Fund is $30 \%$ in Mortgages, Pensions \& Investments 20 (Mar. 3, 
benefit" in this case-housing for pension participants-is clearly direct. If the benefit is less direct, however, a court will probably tolerate less variance froin traditional investing precepts. At the extreine would be a similar investment $\mathrm{m}$ a housing project located in another part of the country. The commitment of funds to such a project would probably be imprudent. The determination in this case would rest on such factors as the size of the investment, the probable rate of return, the risk of corpus dissipation, and the presence of trust authorization for the imvestment decision.

\section{Summary}

A trustee may decrease the uncertainty of promotimg nontraditional investment objectives by carefully evaluatimg the three factors discussed in this section. The type of trust, the contents of the authorizing document, and the nature of the "other benefits" that an investment provides will affect the trustee's freedom to pursue nontraditional goals. Thus, for example, a Uniform Act trustee who is authorized to pursue nontraditional goals and whose investment will provide direct "other benefits" should feel relatively free to pursue nontraditional imvestment strategy. On the other hand, an ERISA trustee who does not have such authorization and whose investments will not yield direct "other benefits" should be conservative in his or her pursuit of nontraditional objectives.

\section{CONCLUSION}

This Article explored whether trustees may promote nontraditional investment objectives at the expense of return and corpus safety - the traditional goals-consistently with the prudent man standard. It demonstrated that there are numerous interpretations of the standard that will permit such an undertaking. Although the law has not settled on any particular interpretation, there is ample reason to beheve that courts will ultimately give trustees considerable freedom to foster nontraditional goals.

A word of caution to trustees is appropriate. Trustees who opt to. proinote nontraditional objectives through their investments should perceive that the attainment of the traditional objectives will contimue to be the norm. That is, the trustee's primcipal obligation under the prudent man standard, however innovatively interpreted, will contimue to be to obtam an adequate return and protect the trust corpus. Courts will permit some deviations from this norm. Trnstees, nevertheless, will have to justify such deviations in light of the factors set forth in this Article.

1980) ("The state of Hawaii's Employees [sic] Retirement System has about 30\% of its . . . fund in [mortgage loans] . . . for its members and pensioners."). 